\title{
ANALYSIS OF EFFECTIVENESS AND EFFICIENCY OF PADANG PUSKESMAS EXPENDITURE BUDGET REALIZATION 2016-2019
}

\author{
${ }^{12}$ Afiatin Nisa, Nani Hanifah \\ Departement of Accountinng, STIE Widya Gama Lumajang ${ }^{1}$ \\ IAIN Fattahul Muluk Papua ${ }^{2}$ \\ Email: afuiatinnisa@gmail.com
}

\section{A R T I C LE INFO}

Date of entry:

14 Januari 2020

Revision Date:

16 February 2020

Date Received:

5 June 2020

\begin{abstract}
A B S T R A C T
The purpose of this study was to determine the Effectiveness of Realized Budget Expenditures at the Padang Health Center and to determine the Realization Efficiency of the Padang Puskesmas Expenditure Budget for the 2016-2019 Budget Year. In the author the method used in research is quantitative. The results of the study showed that the level and criteria for the effectiveness of the expenditure budget realization at the Puskesmas Padang in the 2016-2019 Fiscal Year and 2019 proved effective. For the 2017 Budget Year the effectiveness criteria level proved to be quite effective. The level of efficiency in the Realization of Expenditures at Padang Health Centers in Fiscal Year 2016,2018 and 2019 proved to be efficient. In the 2017 Budget Year the efficiency criteria level proved to be quite efficient.
\end{abstract}

Keywords: Effectiveness, Efficiency and Budget Realization Reports

Cite this as: Nisa, Afiatin., Setyobakti, Moch. Hudi., Liyundira, Fetri Setyo. (2020). ANALYSIS OF EFFECTIVENESS AND EFFICIENCY OF PADANG PUSKESMAS EXPENDITURE BUDGET REALIZATION 2016-2019.. Assets : Jurnal Ilmiah Ilmu Akuntansi, Keuangan dan Pajak, 4(2), 78-82.

\section{INTRODUCTION}

According to Mardiasmo (2009) efficiency is closely related to the concept of productivity. Efficiency measurement is done by comparing the output produced to the input used (cost of output). The process of operational activities can be said to be efficiency if a product or work can be achieved with the lowest possible use of resources and funds (spending well).

According to Handoko (1995: 5) Effectiveness is the ability to choose the right or the right equipment to achieve the goals that have been set. In other words, it is said to be effective if it can choose the right work to be done or the right method to achieve the goal. So the concept of effectiveness is a comprehensive statement of how far an organization has achieved its goals. Effectiveness can also mean activities that are completed on time according to a predetermined plan,

The financial report is an agenda in fulfilling obligations for common needs as stipulated in the prevailing laws and regulations. The presentation of financial statements is prepared by the government and must include a component of financial statements. One of the components of the 
financial statements is the budget realization report prepared by the entity, an entity will present a budget realization report based on the basis stipulated in the laws and regulations.

The budget realization report provides useful information in predicting economic resources that will be received to finance central and regional government activities in the coming period by presenting a comparative report. The budget realization report can provide information to report users about the indication of the achievement and use of economic resources that have been implemented effectively and efficiently in accordance with the budget (APBN / APBD), and have been carried out in accordance with laws and regulations..

\section{METHODS}

This type of research is a descriptive method with a quantitative approach. Descriptive method is a study of problems or problems in the form of present facts from a population. The object of this research is the Effectiveness and Efficiency of Budget Realization at Puskesmas Padang. The type of data in this study is secondary data. Secondary data is a source of research data obtained indirectly but through intermediaries or other parties. In general, secondary data is in the form of evidence, records, or historical reports that have been archived. In this study, the data were the Padang Public Health Center Expenditure Budget Realization Report data taken in 2016-2019. Sources of data in this study are internal data or data obtained from inside in the form of a 20162019 expenditure budget realization report at Puskesmas Padang.

The method used is the documentation method. The documentation method is a technique of collecting data, recording data and copying data from existing documents. In the research data was collected, namely secondary data derived from data from related agencies, namely Padang Health Center 2016-2019.

\section{RESULTS AND DISCUSSION}

Planning at the Puskesmas is to formulate plans for proposed activities, this must take into account the various policies that apply globally in accordance with the results of a study of data and information at the Puskesmas. The RUK must be complemented with proposed financing for the routine needs, facilities, infrastructure and operations of the Puskesmas. The RUK that has been prepared is discussed at the Health Office and submitted to the District Government through the Health Office. The RUK summarized in the Health Office proposal will be submitted to the DPRD for financing approval. After receiving DPRD approval, it is submitted to the Puskesmas through the Health Office.

Budget User / Property User Officials prepare a Work Plan and Budget (RKA) in accordance with Government Regulation Number 58 of 2005 concerning Regional Financial Management and Regulation of the Minister of Home Affairs Number 13 of 2006, last amended by Permendagri Number 21 of 2011. The preparation of the RKA takes into account the link between funding and output and the results of activities and programs including efficiency in achieving outputs and outcomes. The preparation of the budget includes:

1. Performance indicators measure the success achieved in each Puskesmas program and activity.

2. Performance targets measure the work performance to be achieved from the original state and consider the factors of quality, quantity, efficiency and effectiveness of the implementation of each program and activity.

3. Analysis of the standard expenditure assessment of the fairness of the workload and costs used in carrying out activities. This analytical approach is carried out in stages according to needs. 
The next stage is the Regional Government Budget Team, regional financial management officials, to verify the draft DPA within 15 working days from the enactment of the regional head regulation on APBD. The regional financial management officer certifies the DPA with the approval of the regional secretariat. The approved DPA is used as the basis for budget execution by the head of budget users / goods users

Every expenditure implementation for Puskesmas expenditure must be supported by documentary evidence, namely complete and valid. The evidence must be validated, verified by a financial official at the Health Office on the correctness of the material from the use of the evidence. The documentary evidence includes: SPJ for various activities in community service, Contract Documents with third parties and proof of income tax $(\mathrm{PPh})$ collection and other taxes.

The data used in this research is quantitative data which is secondary data. Secondary data is data obtained through data that has been researched and collected by other parties relating to research problems obtained from the institution concerned to support research results

Table 1. The Realization Of The 2016 Budget Budget

\begin{tabular}{clcc}
\hline $\begin{array}{c}\text { Account } \\
\text { Code }\end{array}$ & \multicolumn{1}{c}{ Description } & BUDGET (idr) & Realization \\
\hline $\mathbf{1}$ & \multicolumn{1}{c}{$\mathbf{2}$} & $\mathbf{3}$ & $\mathbf{4}$ \\
\hline 4 & INCOME & 1.134 .875 .963 & 1.263 .467 .450 \\
4.1 .2 & Result of Regional Retribution & 66.380 .000 & 90.315 .200 \\
& Other Legitimate Original Regional & 1.068 .495 .963 & 1.173 .152 .250 \\
4.1 .4 .018 & Income & 1.673 .821 .734 & 1.463 .749 .380 \\
\hline
\end{tabular}

Source: Budget Realization Report

\section{CONCLUSION}

This research used mining sector companies in 2011-2015, as many as 26 companies were sampled. Disclosure of environmental accounting is an independent variable (X) that is measured using an appropriate rating, while stock performance is a Dependent variable (Y). And based on the results of data analysis processed in the SPSS Version 16 application, it can be concluded as follows: If a company is registered to join this program, then the company will get the right rating, there are five appropriate ratings (black, red, blue, green, and gold.) Which means a company that gets a black rating means that the company in dealing with postal accounting environmental post is very bad. And if the company gets the value of gold, then the company is already very worried about overcoming its posts.

From the table above, in 2016 the direct expenditure budget for Puskesmas Padang was Rp. $1,673,821,734$ with a realized amount of Rp. 1,463,749,380, consisting of personnel expenditure, goods and services expenditure, and capital expenditure and machine tools. With a budget of revenue of IDR 1,134,875,963 and a realization of IDR 1,263,467,450.

Summary of the report on the realization of the Puskesmas Padang budget for the 2017 fiscal year that the total income is IDR 1,715,732,000 and Puskesmas Padang receives IDR 1,423,485,550. Padang Puskesmas revenue consists of the results of local fees, public service fees, business service fees and local revenue. The direct expenditure budget for Puskesmas Padang is Rp 2,315,460,641 consisting of personnel expenditure, goods and services expenditure and capital expenditure for equipment and machinery with a total realization of $\mathrm{Rp} 1,840,537,264$. 
The results of the data on the realization of the Padang Puskesmas budget report for the 2018 Fiscal Year, the total revenue of Puskesmas Padang was IDR 1,405,270,000 and realized IDR 1,395,722,425. The income of Puskesmas Padang consists of local fees, public service fees, business service fees and other legitimate local revenue. The expenditure budget for Puskesmas Padang for Fiscal Year 2018 is IDR 2,144,189,927 with realization of IDR 1,795,480,198 consisting of personnel expenditure, goods and services expenditure, capital expenditure and machine tools and building and building capital expenditure.

The 2019 budget realization report with a total income budget of IDR 1,344,924,795 with a realization of IDR 1,868,604,875 consisting of the results of regional levies, public service fees, business service fees and other legitimate original regional income. The budget ceiling for direct expenditure for Puskesmas Padang is Rp. 2,025,682,200 and the realization is Rp. 2,185,756,097 consisting of personnel expenditure, goods and services expenditure, capital expenditure and machine tools, building and building capital expenditure and other fixed asset capital expenditures

\section{CONCLUSION}

The results of the effectiveness and efficiency analysis and the researchers' discussion will provide conclusions including:

1. The results of the effectiveness analysis concluded that the realization of the Puskesmas Padang expenditure budget was relatively effective even though in 2017 it was less effective, where activities or expenditures sourced from DAK funds were not realized, which consisted of personnel spending and goods and services expenditures. Ineffective because of every program and budget planned, many programs are realized but not in accordance with the planned budget and there are also programs that are not realized until the limit of the fiscal year.

2. The results of the analysis of the efficiency of the direct expenditure budget do not exceed the expenditure budget or are said to be efficient. Puskesmas Padang can use the existing expenditure budget and not over-budget or exceed the target, because later if the realization of the expenditure budget exceeds the target, the regional finance party will be held accountable and asked for data starting from expenditure, official travel documents and Puskesmas debt in the previous year.

\section{REFERENCE}

Budiarso, N., Tinangon, J., \& Rondonuwu, R. (2015). Analisis Efisiensi dan Efektivitas Pengelolaan Keuangan Daerah pada Dinas Pendapatan Daerah Kabupaten Minahasa. Jurnal Riset Ekonomi, Manajemen, Bisnis Dan Akuntansi, 3(4), 23-32.

Pinatik, S., \& Pangkey, I. (2015). Analisis Efektivitas Dan Efisiensi Anggaran Belanja Pada Dinas Kebudayaan Dan Pariwisata Provinsi Sulawesi Utara. Jurnal Riset Ekonomi, Manajemen, Bisnis Dan Akuntansi, 3(4), 33-43.

Akuntansi, J., \& Ekonomi, F. (2016). Analisis Efektifitas Dan Efisiensi Pelaksanaan Anggaran Belanja Badan Perencanaan Pembangunan Daerah (Bappeda) Kota Manado. Jurnal Berkala Ilmiah Efisiensi, 16(3), 616-623.

Rahayu, R. P. (2018). Daerah kota Kediri oleh: Reny Pujining Rahayu dibimbing oleh: surat pernyataan artikel skripsi tahun 2018.

Sumenge, A. (2013). Analisis Efektifitas Dan Efisiensi Pelaksanaan Anggaran Belanja Badan Perencanaan Pembangunan Daerah (Bappeda) Minahasa Selatan. Jurnal Riset Ekonomi, Manajemen, Bisnis Dan Akuntansi, 1(3), 74-81.

Pangkey, I., \& Pinatik, S. (2015). Analisis Efektifitas dan Efisiensi Anggaran Belanja pada Dinas Kebudayaan dan Pariwisata Provinsi Sulawesi Utara. Jurnal EMBA, 3(4), 33-43.

Anita, B., \& Suryani, D. (2013). Dalam Upaya Efisiensi Dan Efektifitas Pelayanan Policy Analysis of Bengkulu City Health Insurance As an. 02(02), 151-160. 
Untari, R. (2015). Analisis efisiensi dan efektifitas pelaksanaan realisasi anggaran belanja langsung dinas pendidikan kota semarang. UniversitasDian Nuswantoro: Semarang.

Kartika, D., Setiawan, A., \& Kusuma, I. (2016). Analisis Ratio Kemandirian, Rasio Efektivitas PAD, dan Rasio Efisiensi PAD pada Laporan Realisasi Anggaran Pendapatan dan Belanja Daerah (APBD) Kabupaten Sukabuki. Jurnal Sosial Humaniora, 7(2), 143-151.

Sujarwoto. (2016). Jurnal Ilmiah Administrasi Publik (JIAP). Jurnal Ilmiah Administrasi Publik (JIAP), 2(4), 227-235.

Pamungkas, B. D., . W., \& Firmansyah, M. (2016). Analisis Efisiensi Puskesmas di Kabupaten Sumbawa Tahun 2015. Jurnal Ekonomi Dan Ekonomi Studi Pembangunan, 8(2), 183-206 